\title{
A bomba - o testemunho de Arrupe
}

\section{PEDRO MIGUEL LAMET}

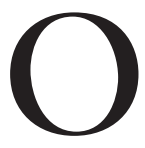

RELÓGIO continuava imóvel, cravando em sua imaginação, com os ponteiros permanentemente parados na mesma hora: $8 \mathrm{~h} 15$. Com a cabeça entre as mãos, viu sua vida inteira até aquele momento cruzar ante seus olhos num só instante: desde os albores, às margens do Nervión, em Bilbao, até esse momento eterno que iria dividir sua existência em dois grandes capítulos: antes e depois da bomba.

$\mathrm{Na}$ solidão tranquila da capela, Pedro Arrupe pedia luz: precisava fazer algo! Reavivaram-se subitamente em sua memória, passando como um filme, todos os acontecimentos que tinham precedido aquele fatídico 6 de agosto de 1945.

Até então havia apenas a presença do vago fantasma da guerra. Hiroshima vivia tranquila no meio da escassez, com seus quatrocentos mil habitantes, aglomerados em típicas casas japonesas de um ou dos andares, feitas de madeira, com exceção de alguns grandes edifícios de concreto, apinhados no centro da cidade e dominando a planície.

De vez em quando, com regularidade semanal, Arrupe via o duplo desfile de uniformes novos ou rasgados dos que iam para a frente de guerra e dos que de lá voltavam. O porto de Hiroshima tronou-se porto militar de embarque e desembarque de tropas.

Parecia, porém, que os americanos se tinham esquecido daquela cidade. Estavam centralizados em Kure ou, mais longe ainda, em Osaka e Kobe. A Hiroshima chegavam apenas os ecos dos bombardeios que continuamente castigavam aquelas povoações.

Nos primeiros tempos, os habitantes de Hiroshima passavam a noite em covas abertas nos montes vizinhos; mas, pelo hábito de constatar, cada dia, que se tratava de alarme falso, o ulular frenético das sirenas já não convencia a população a sair de casa: achavam que era mais arriscado pegar um resfriado nas covas do que esperar os bombardeios.

\section{Operação "Manhattan"}

Muito longe daquela tranquila cidade japonesa, alguns homens, inquietos pelos eventos de Pearl Harbour, sacudiram o pó de um velho projeto... Lembraram-se de que, em 1919, um físico inglês, Ernest Rutherford, conseguira desintegrar um átomo e, em 1938, o químico alemão Otto Hahn levara a termo um experimento decisivo: o bombardeio do urânio por meio de nêutrons. Nos Estados Unidos, ao eclodir a guerra, Enrico Fermi, exilado por incompatibilidade com o regime fascista, estava na vanguarda da pesquisa nuclear, ao lado de Leon 
Szilard e Paul Wigner. Todos contavam com o apoio dos professores Chadwick e Allier, que trabalhavam no Reino Unido, Noruega e França. O próprio Albert Einstein alertara o governo americano para o perigo que rondava o Ocidente, se os alemães chegassem primeiro à fabricação da bomba.

O ataque japonês de 7 de dezembro de 1942 acendeu o estopim da bomba. Os Estados Unidos decidiram pôr em marcha o projeto "Manhattan", cujo fim último era fabricar a primeira bomba atômica da história. $\mathrm{O}$ exército americano recebeu ordens de dar prioridade absoluta ao projeto e nomeou, como primeiro responsável por ele, o general Leslie Groves; este, por sua vez, designou o físico Robert J. Oppenheimer como coordenador geral. Este brilhante pesquisador de 38 anos, de grande capacidade técnica e dotes de mando, pôs em marcha a intricada rede de esforços necessária para realizar o projeto.

Mil cento e quarenta toneladas de mineral rico em urânio, procedentes do Congo Belga, chegaram ao porto de Lobito, acondicionados em dois mil cilindros de aço. A matéria-prima estava disponível.

Centenas de cientistas, técnicos e militares puseram mãos à obra, ignorando - a maioria - a finalidade do seu trabalho. Em Los Alamos, Novo México, no maior isolamento e sigilo, entraram em marcha os cinco procedimentos, a fim de encontrar o método apropriado para isolar o "urânio 235 ” em escala industrial. Outros laboratórios, instalados na Universidade de Colúmbia, na Universidade da Califórnia e em Chicago, continuaram as experiências de laboratório. Ao mesmo tempo, a contraespionagem trazia informações dos avanços da pesquisa nuclear na Noruega, cujas instalações foram sabotadas por comandos aerotransportados.

Em 7 de novembro de 1942, Fermi levou a cabo a experiência decisiva, que evidenciou a viabilidade da esperada reação em cadeia. Dentro de mais um ano, segundo a estimativa de então, poder-se-ia ter pronta a primeira bomba atômica. Em 1944, graças ao empenho e aos fabulosos recursos investidos, o processo de obtenção estava completamente resolvido. Entretanto, a bomba não estava pronta...

Nessa altura dos acontecimentos, ouviu-se, pela primeira vez, o alarme de um cientista. O prêmio Nobel da física, o dinamarquês Niels Bohr, que conseguira fugir do seu país ocupado e refugiar-se nos Estados Unidos, escreveu ao presidente Roosevelt, prevenindo-o da "terrível perspectiva de uma guerra futura entre nações que contassem com arma tão formidável quanto a bomba atômica”.

De fato, naquela data, a Alemanha estava batendo em retirada da frente russa e lutando nas fronteiras da Polônia; assim sendo, a bomba atômica carecia de justificação. A voz de alarme do cientista de nada serviu. Segundo o parecer dos políticos, tinha-se investido dinheiro alto demais no projeto para se poder voltar atrás. Em começos de 1945, a Alemanha estava já irremediavelmente perdida, atacada pelo Leste e pelo Oeste. A marcha das operações contra o Japão já 
estava fechando o cerco em torno das ilhas. Os cientistas Einstein e Szilard, os mesmos que, três anos antes, aconselharam o projeto, dirigiram-se também ao presidente americano para dissuadi-lo de usar a bomba, sob pena de contemplar, no futuro, uma insana corrida em busca de armas atômicas que poriam a humanidade em perigo.

Tudo inútil. Em julho de 1945, no polígono de tiro de Alamogordo a 320 quilômetros de Los Alamos, uma luz branca, deslumbrante, iluminou o deserto, as montanhas e as distâncias em redor... Uma bola vermelha, refulgente, elevou-se até o céu, unida ao solo por uma estela cinzenta. Os cientistas olharam assombrados para aquele primeiro experimento da bomba, que tinha a aparência de uma arma convencional.

Os acontecimentos precipitam-se. Truman recebeu a sugestão de enviar antes um ultimato ao Japão. Chegou-se a um acordo, em Potsdam, no sentido de mandar mensagem aos japoneses, admitindo a continuidade da monarquia em troca de uma capitulação incondicional. $\mathrm{O}$ governo imperial, impulsionado pelo romantismo nacional, decide ignorar a nota, o que, evidentemente, não foi interpretado pelos Estados Unidos como capitulação.

Em 26 de julho, chega à ilha de Tininan, a bordo do cruzador Indianapolis, a carcaça da bomba atômica. Com ela, nesse mesmo navio, uma parte do "urânio 235", enquanto o restante, necessário para obter-se a massa crítica viajava a bordo de um "C-54". O comandante Spaatz pediu ordem expressa para lançar a bomba, recusando-se a "matar talvez umas cem mil pessoas com meras instruções verbais". Exigiu ordem do comandante em chefe: o próprio presidente.

O alvo escolhido foi Hiroshima, seguida de Kokura e Nagasaki. Um "B29" foi encarregado de sobrevoar a zona regularmente, para assegurar a visibilidade. O bombardeiro escolhido para lançar a bomba atômica foi batizado com o nome de Enola Gay, nome da mãe do piloto, o coronel Tibbets, que seria escoltado por dois "B-29".

A bomba, de três metros de cumprimento e um metro e meio de diâmetro, foi montada em pleno voo pelo capitão William S. Pearson, com o dispositivo de disparo regulado para explodir a seiscentos metros antes de tocar o solo. Naquele momento, ninguém sabia que efeitos teria a bomba atômica estourando a essa altura. ${ }^{1}$

Finalmente chega a ordem de Truman em 5 de agosto.

No dia seguinte, a 1h37, os três "B-29" decolaram de Tininan, depois de uma oração do capelão das forças armadas. O que aconteceu com Paul Tibbets e os outros tripulantes a bordo do Enola Gay, já o conhecemos. ${ }^{2}$

Lá embaixo, na cidade de Hiroshima, tudo tranquilo. A população japonesa dorme. Muito antes do nascer do sol, Pedro Arrupe levanta-se, como todos os dias, para orar. Já era habitual que, às $5 \mathrm{~h} 30$, se ouvisse o ronco dos motores de um "B-29". Cruzando pontualmente o céu da cidade. Às 7h55, um segun- 
do toque de alarme indicou que o inimigo se aproximava. Um outro "B-29" passou, muito mais alto, sem que ninguém lhe desse atenção. Às $8 \mathrm{hl}$, soou o toque de fim de perigo, e a população já se dispunha a retomar a rotina de mais um dia.

Pelo nariz transparente do Enola Gay, Paul Tibbets observa com perfeita nitidez, a uns dez mil metros de altura, a cidade que desperta: lá está, num dia claro, delineada pelos sete dedos do promontório de Ota. Hiroshima, ainda intacta e sem desconfiar sequer de que estava a ponto de receber seu trágico "batismo atômico". Às 8h13:30, Paul Tibbets dá a ordem ao seu bombardeiro, o major Tom Forebbe.

A bomba saiu das comportas do avião exatamente às 8h15:17. Aliviado de sua carga de cinco mil quilos, o Enola Gay dá um verdadeiro salto rumo ao céu e ganha altura. A tripulação sabe que dispõe de quarenta segundos para afastar-se: depois desse tempo o avião deve encontrar-se a 18 quilômetros de distância do epicentro da explosão. Cada um daqueles quatro homens faz sua contagem regressiva: “40... 39... 38...”.

Ouve-se um estalido de resplendor incrível a explodir bem no coração da matéria, inundando o céu e cegando os olhos dos aviadores, protegidos por óculos próprios para solda autógena. Imediatamente depois, gigantesca nuvem elevou-se em forma de seta, silhuetando-se no céu.

O presidente Truman, em alto-mar, a bordo do cruzador Augusta, estava de mau humor por causa do encontro de Potsdam, que terminara tristemente num desacordo histórico entre Estados Unidos e União Soviética. Ele passeava pela coberta do navio, ouvindo a orquestra, enquanto esperava notícias da bomba. Passado algum tempo, dirigiu-se ao restaurante. Nesse momento, chega um dos seus ajudantes com um despacho telegráfico: "Results clear cut succesfull in all respects. Visible effects greater tham any tests". Nas suas memórias, Truman matizou bastante a sua reação; no momento, porém, o que ele realmente disse foi: "Rapazes! Jogamos em cima deles um tijolo equivalente a 20.000 toneladas de dinamite!" E os marinheiros gritaram de alegria. ${ }^{3}$

\section{O Pika-don}

Em Hiroshima, ninguém ouviu ruído algum. Uma terrível claridade, como de um relâmpago branco e púrpura, invadiu tudo em um segundo e logo se transformou em apavorante e gigantesco incêndio. Os bondes se transformaram em túmulos de ferro retorcido, repletos de cadáveres calcinados sobre os assentos ou amontoados sobre as plataformas. Um vendaval de 1.200 quilômetros por hora surgiu repentinamente, derrubando muros e paredes, num raio de 1.500 metros, quebrando vidraças a 12 quilômetros do epicentro. Foi um ciclone que durou seis horas. A temperatura atingiu 50 milhões de graus centígrados. Hiroshima vivia o dia mais trágico de sua história.

Naquele momento, as sirenas haviam parado de tocar - diz Arrupe -, passaram-se apenas cinco minutos - eram 8 hl 5 - quando um fogaréu, como o 
do magnésio, rasgou o azul do céu. Eu que me encontrava em meu gabinete, com outro jesuíta, pus-me de pé imediatamente e fui à janela. Naquele momento, um mugido surdo e continuado, mais como o de uma cachoeira que se despeja ao longe, do que como o som de uma bomba explodindo repentinamente, chegou aos nossos ouvidos com força aterradora. A casa tremeu. Os vidros da janela caíram espatifados; as portas foram arrancadas dos gonzos e os tabiques japoneses, feitos de barro e caniço, se quebraram como cartas de baralho amassadas por mão gigantesca. Aquela força terrível, que nos parecia estar arrancando a casa pelos fundamentos, derrubou-nos no chão como uma tremenda bofetada invisível. Enquanto cobríamos a cabeça com as mãos, num gesto instintivo de defesa, uma demorada chuva de destroços caía sobre nossos corpos estendidos e imóveis sobre o soalho. Passado aquele terremoto, pusemo-nos de pé, temendo cada um de nós que o outro estivesse ferido. Felizmente, estávamos ambos incólumes, sem mais consequências que as contusões naturais da queda. Saímos logo a percorrer a casa, preocupados com os trinta e cinco jovens jesuítas que estavam sob minha responsabilidade. Fui de quarto em quarto, até o último e não encontrei ninguém ferido. ${ }^{4}$

Imediatamente depois, num movimento instintivo, Arrupe saiu para o jardim em busca da bomba... Não encontrou nada além de comprovar os estragos da casa. Subiu, então, ao alto da colina donde, dirigindo o olhar para a planície do leste, viu que Hiroshima inteira ardia em chamas.

Mais tarde ele reconstruiu seus dados:

O ruído foi muito pequeno, veio acompanhado de um fogaréu que nos deixou a impressão de uma explosão de magnésio. Durante alguns momentos, alguma coisa, seguida de uma nuvem vermelha de chamas, caiu rapidamente e estalou de novo, desta vez com força espantosa, a uma altura de quase quinhentos e setenta metros sobre a cidade. A violência desta segunda explosão foi indescritível. Labaredas azuis e vermelhas espirraram em todas as direções e, logo, em seguida, ouviu-se um trovão assustador, acompanhado de insuportáveis ondas de calor, que caíram sobre a cidade arrasando-a. Tudo quanto podia arder ficou calcinado e os metais se derreteram.

Tudo isto foi a tragédia dos primeiros momentos. No instante seguinte, uma gigantesca montanha de nuvem torvelinhava no céu. Bem no centro da explosão, apareceu uma terrível bola da qual partiu uma onda de gases que, com velocidade de uns oitocentos quilômetros por hora, varreu tudo quanto se achava num raio de seis quilômetros. Finalmente, dez minutos mais tarde, uma espécie de chuva negra caiu sobre o noroeste da cidade.

Os japoneses, sem saber ainda que acabara de estourar sobre eles a primeira bomba atômica, designaram o fenômeno de Pika-don, por causa da harmonia imitativa da sua língua. Pika era para eles o fogaréu assustador e don o ruído explosivo que se seguiu depois. ${ }^{5}$

Para Pedro Arrupe, como para todo mundo, tudo aquilo era inexplicável. Já vira explodir muitas bombas e granadas, durante quatro anos de guerra: mas 
o que acabara de acontecer era algo completamente diferente. É verdade que ouvira falar, naqueles tempos, de armas secretas; mas pensava sempre que se tratasse de mais uma propaganda bélica.

Num primeiro impulso, Arrupe pensou em correr logo até o centro da cidade, a fim de socorrer os feridos e, mais concretamente, os jesuítas que viviam numa residência no centro de Hiroshima. Mas era impossível dar sequer um passo, porque o fogo fechava todos os caminhos, enquanto uma fumaça negra e densa saía dos edifícios em chamas e envolvia a cidade.

Foi então que decidiu ir à capela. Uma das paredes tinha caído em pedaços. Em meio à escuridão, Pedro pediu luz. Foi um instante eterno, como uma linha equatorial dividindo sua vida: antes da bomba e depois dela. Todos os relógios de Hiroshima estavam parados; mas Arrupe consultou um tempo sem tempo maias acima, para além dos acontecimentos humanos.

Havia morte e destruição por todos os lados, e nós aniquilados pela impotência. E Ele ali, sabendo tudo, contemplando e esperando nosso convite para que tomássemos parte da obra de tudo reconstruir.

\section{Hospital improvisado}

Ao sair da capela, a decisão foi imediata: transformaríamos a casa em hospital... Lembrei-me dos meus conhecimentos de medicina, adquiridos em anos já bem distantes, sem prática ulterior; aqueles momentos, porém, fizeram de mim um médico e cirurgião. Fui atrás da maleta de primeiros socorros e a encontrei entre as ruínas, destroçada, sem nada de aproveitável, além de um pouco de iodo, algumas aspirinas, sal de fruta e bicarbonato. E as vítimas eram mais de duzentas mil! Por onde começar? Era mister agir sem remédios e esta realidade impôs o procedimento a ser adotado. Estávamos diante de naturezas já desgastadas por uma guerra duríssima, em que os alimentos escasseavam havia já muito tempo. Aquelas pessoas tinham um fundo de tuberculose, coisa comum em milhões de japoneses; precisávamos, pois, fortificá-los, a fim de duplicar suas energias para a convalescença. Era urgente dar-lhes de comer em abundância... e, entretanto, nada tínhamos na despensa. Como os japoneses todos, também nós vivíamos de escassa porção de arroz que nos permitiam, ração tão minguada que não deixava margem para economia. ${ }^{6}$

Arrupe entendeu claramente que devia usar seus noviços.

- Vão por onde Deus os conduzir e tragam comida... qualquer coisa! Não me façam perguntas; pouco importa onde a encontrem ou como: emprestada, comprada ou ganha! O importante é que os feridos que aqui estarão quando voltarem tenham o que comer quanto antes.

Ninguém lhe replicou palavra.

Efetivamente, passados alguns minutos, surgiram os primeiros feridos, como fantasmas ambulantes; pedaços de pele pendiam dos corpos, às vezes fundidos com os trapos queimados de roupa que flutuava ao vento. Vinham cheios de bolhas, manchas vermelhas, roxas e negras... Vinham tateando, sem saber o que thes ocorrera nem quando desabara sobre eles tanto horror. E foram che- 
gando ao hospital improvisado do Pe. Arrupe. As primeiras vítimas foram umas jovens operárias; logo depois crianças que chamavam por seus pais aos gritos e, um pouco mais tarde, anciãs transtornadas pela catástrofe, que a duras penas conseguiram se arrastar de sob as ruínas de suas casas destroçadas; finalmente chegou um grupo de soldados.

Havia esgares de horror em todos os rostos, como se tivessem acabado de escapar do inferno. Tremiam de dor e de medo, contorcendo-se no chão, desfalecendo de debilidade.

Arrupe não para. Transforma em enfermaria a biblioteca e a sala de visitas, e em sala de cirurgia o gabinete do reitor.

Limpar as feridas é a primeira coisa que faz.

Muitas - escreve mais tarde - eram consequências de contusões produzidas pelo desabamento das casas; eram fraturas de ossos e cortes, diferentes das feridas provocadas por balas ou lâminas de baionetas, que deixam limpos os lábios das chagas... Eram ferimentos originados por desabamentos, pela pressão de vigas que caíam sobre os corpos, pela chuva e pelas telhas pulverizadas, triturando e rasgando a massa muscular, deixando incrustados poeira, cacos de vidro e pontas de madeira, sem falar em pequeninas lascas dos próprios ossos quebrados. Havia também feridas limpas, causadas por pedaços de vidro, mais fáceis de limpar e menos propensas a infecção. Mas o que mais aparecia eram as queimaduras. Houve alguém que veio, várias horas depois da explosão, transformado numa só bolha gigantesca que lhe cobria o peito, o ventre e as costas. ${ }^{7}$

Quando o Padre perguntava a alguém como se queimara daquela maneira, a resposta era sempre a mesma: estavam dentro da própria casa quando esta desabou. Logo tudo se incendiou e eles se queimaram enquanto tentavam desesperadamente escapar dos escombros incandescentes.

Tudo isso era natural; havia, porém, outro tipo de queimaduras cuja origem era inexplicável.

Arrupe perguntou:

- Como se queimou?

- Eu não me queimei, Padre.

- Mas, então, que lhe aconteceu?

- Não sei. Vi uma luz, ouvi uma explosão terrível e não me aconteceu nada; meia hora depois, percebi que se iam formando em minha pele umas pequenas bolhas superficiais; umas quatro ou cinco horas mais tarde, tudo era uma queimadura só, que começou a supurar no dia seguinte. E isso sem fogo algum!

Era desconcertante - escreveria Arrupe, anos mais tarde -. Hoje sabemos que se tratava dos efeitos das radiações infravermelhas que atacam os tecidos e produzem não só a destruição da epiderme e da endoderme, mas também dos tecidos musculares, causando aquelas supurações, causa de tantas mortes e de tanta desorientação para nós. ${ }^{8}$ 
Para limpar as feridas, era necessário abrir as bolhas. Depois de quatro horas e meia de trabalho, Arrupe já tinha cento e cinquenta pessoas em casa, com quase a metade da superfície do corpo em carne viva.

Além disso - prossegue Arrupe -, o trabalho era muito penoso, pois quando se produz uma pequena bolha no pé, por exemplo, devido à fricção de um sapato, faz-se uma ligeira punção com um alfinete, sai uma gotinha d'água e pronto; mas, quando essa bolha toma conta da metade do corpo, a mesma punção faz sair mais de cento e cinquenta centímetros cúbicos de água! A princípio usávamos umas pequenas cubas niqueladas; a partir, porém, do terceiro curativo, vendo tudo que saía daquelas queimaduras, começamos a usar caldeirões, baldes e quanto vasilhame encontrávamos pela casa.

Eram sofrimentos espantosos, dores terríveis que os forçavam a contorcerem-se no chão como serpentes; no entanto, não se ouvia uma queixa ou gemidos: todos sofriam em silêncio. Ninguém gritava nem chorava. Nisto é que o povo japonês se manifesta superior ao ocidental; no controle absoluto da dor e no seu estoicismo, tanto mais admirável quanto mais espantosa a hecatombe.

Depois de algum tempo, chegaram as religiosas da cidade, cujo convento fora destruído, não pela força da explosão, mas pelo fogo. Todas elas saíram ilesas; apenas uma apresentava ligeiras queimaduras na mão.

Chegou um momento em que o hospital de Arrupe estava abarrotado, sem poder receber nem um ferido a mais. O terrível espetáculo continua, porém com uma constante procissão de miséria, desfilando pelas ruas e caminhos que vêm de Hiroshima. É uma longa fila ininterrupta de corpos meio queimados que avançam cambaleando, enquanto procuram afastar-se, quanto suas pernas o permitam, do lugar de seu desespero.

Quase todos os automóveis da cidade foram destruídos pelo fogo, e os bondes suburbanos ficaram sem energia elétrica nem trilhos, que o desastre retorcera. Arrupe e seus jovens ajudantes colaboram para levar toda essa gente à primeira estação de socorro: aí perguntam qual poderia ser o método mais adequado para tratar as queimaduras. Mas, ninguém entende nada. Os próprios médicos confessam que nunca tinham enfrentado semelhante patologia; feridas que não eram o resultado direto do calor e do fogo... Uma espécie de raio afetava os tecidos da pele, mais ou menos profundamente, atingindo até mesmo os ossos.

Arrupe continuava sem remédios nem gazes. Felizmente, porém, sua intuição inicial deu resultado. Seus emissários conseguiram boa quantidade de alimentos junto aos generosos camponeses dos arredores. Os conhecimentos médicos do missionário acertaram na terapia: sobrealimentar aqueles corpos destroçados, a fim de esporear a capacidade de autocura do organismo. Excetuando um menino que faleceu de meningite, pelo aumento da pressão do líquido cefalorraquidiano, todos os demais entraram em pronto restabelecimento, que terminou em cura completa. 


\section{Um deserto de cinzas}

Finalmente, nas primeiras horas da tarde, os jesuítas de Nagatsuka conseguiram entrar em Hiroshima. Como sempre acontece nos grandes incêndios, houve uma enorme concentração de vapor de água que terminou por condensar-se em chuva torrencial que apagou o fogo, pelo menos na parte superior dos escombros.

Eram cinco da tarde - conta Arrupe -. Um espetáculo simplesmente indescritível surgiu ante nossos olhos; uma visão macabra e dantesca que desafia até a imaginação. Tínhamos diante de nós uma cidade completamente destruída. Avançávamos caminhando sobre escombros, ainda ardendo por baixo. Qualquer descuido podia ser-nos fatal.

Muito mais terrível, no entanto, era o quadro trágico de milhares de pessoas feridas, queimadas, pedindo socorro... Como aquele menino que encontrei, com um caco de vidro cravado na pupila esquerda; ou aquele outro que trazia uma haste de pau cravada nas costas, como se fosse um punhal.

O coitadinho soluçava e gritava;

- Salve-me, por favor, não aguento mais!

Ou ainda um terceiro, preso entre duas vigas, já com as pernas completamente queimadas até os joelhos...

Avançávamos, quando vimos, de repente, um jovem que vinha para nós, correndo como louco, aos gritos de socorro; havia já vinte minutos que estava ouvindo a voz de sua mãe, sepultada viva sob as ruínas da própria casa. As chamas já a estavam atingindo, enquanto ele fazia esforços impossíveis para remover as pesadas vigas de madeira que a mantinham presa. Muito mais impressionantes eram os gritos das crianças, chamando por seus pais. Outras já tinham perecido, como as duzentas alunas de um colégio: o telhado desabou em cima delas e não houve uma só que conseguisse escapar das chamas. ${ }^{9}$

Lá pelas dez da noite, Arrupe e seus companheiros encontram finalmente, naquele caos de ruínas, a residência dos jesuítas. Os cinco padres estavam feridos. Pe. Schefer, moribundo. Tinha uma ferida na cabeça e, para estancar a hemorragia, na falta de outra coisa, fizeram-lhe um turbante com jornais e uma camisa. Entretanto, não perceberam outra ferida que Arrupe encontrou atrás de uma das orelhas; um pedaço de vidro seccionara uma pequena artéria, e o padre esvaía-se em sangue.

Decidiram leva-lo para Nagatsuka, em cima de uma tábua rústica, ajeitada entre dois pedaços de bambu, maca improvisada. Schefer, fazendo um gesto de dor, mas sorrindo como um japonês, disse:

- Pe. Arrupe, pode dar uma olhada nas minhas costas? Acho que deve haver algo aí.

Viraram-no sobre a tábua e, à luz de uma tocha, Arrupe viu que as costas do Padre estavam crivadas de pontas de vidro.

Com a ajuda de uma navalha, na falta de bisturi, o Pe. Arrupe tirou mais 
de cinquenta fragmentos e, logo após essa operação, começaram o caminho para a casa do noviciado, avançando no escuro, entre ruínas.

Paravam a cada cem metros para descansar um pouco. Numa dessas paradas, todos escutaram gemidos que pareciam vir de bem perto, se bem que nada vissem ao redor. Não conseguiram identificar logo donde vinham os lamentos, até que alguém disse, aguçando o ouvido:

- É daqui, debaixo de nós, que estão gritando.

Realmente, o pequeno grupo tinha parado bem em cima de um telhado que desabara. Afastando as telhas, acharam uma anciã que tinha quase todo o corpo queimado; só lhe restava um fio de vida, depois de ter ali passado o dia inteiro sepultada. Tiraram-na, e morreu logo em seguida.

Ainda haviam de presenciar várias cenas de horror naquela noite, que se tornou apavorante quando chegaram ao rio Terma... Fugindo do fogo e aproveitando a maré baixa, a multidão enchia ambas as margens. Havia quem afastasse os cadáveres para poder beber água. À meia-noite, porém, começou a subir a maré; os feridos, muito debilitados e meio atolados na lama do fundo, não podiam se mover. "Nunca mais me esquecerei - diz Arrupe - dos gritos daqueles que sentiam já a água no pescoço, sem salvação possível." 10

Padre Arrupe não dormiu naquela noite, como não o faria tampouco nos dias sucessivos, mantido de pé por uma força interior que o levava a estar ao lado daqueles infelizes.

\section{Missa sobre Hiroshima}

Seriam cinco hora da manhã, quando Arrupe e seus companheiros chegaram ao seu destino. Depois de alguns curativos de urgência, ele se dispôs a celebrar a missa.

Ao voltar-se para dizer o Dominus vobiscum, olhou impressionado o panorama. Uns cinquenta japoneses feridos, sentados ou deitados sobre o tatame da capela, tinham os olhos fixos nele. Não conseguiam entender aquela cerimônia, mas viam um homem que não parara um minuto no afã de salvá-los. Ao dirigir-se ao extremo do altar, a fim de ler a epístola ou o evangelho, tinha de desviar suavemente, com o pé, as crianças que ali se aglomeravam, ansiosas por verem de perto aquele estrangeiro que usava roupas tão curiosas e fazia gestos tão misteriosos...

Anos mais tarde, Arrupe assim descreveu assim aquele momento irrepetível:

O ambiente não era, realmente, muito propício para a celebração de uma missa. A capela, semidestruída, estava repleta do estremecimento de enfermos que jaziam no solo, apoiados uns nos outros, sofrendo atrozmente e contorcendo-se de dor. Comecei a missa como pude, no meio daquela massa humana que não tinha a menor ideia do que estava acontecendo ali no altar. Jamais me esquecerei da terrível impressão que tive no momento em que me virei para eles, ao Dominus vobiscum (era ainda a missa em latim, 
de costas, para a assembleia) e contemplei aquele espetáculo do altar. Não me saiu palavra, fiquei paralisado, de braços abertos, contemplando aquela tragédia: a ciência humana, o progresso técnico posto a serviço da destruição do gênero humano. Eles me olhavam com olhos cheios de angústia, de desespero, como se esperassem que lhes viesse algum consolo daquele altar. Cena terrível! Poucos minutos depois. Aquele de quem João Batista dissera "Está no meio de vós Alguém que não conheceis" "ll estava sobre o altar.

Nunca senti, como então, a solidão da incompreensão pagã para com Jesus Cristo. Ali estava o Salvador deles que por eles dera a vida... "mas não sabiam que Ele se encontrava bem no meio deles". ${ }^{12}$ Apenas eu o sabia. Uma oração por aqueles que haviam tido a crueldade de lançar a bomba saiu espontaneamente de meus lábios: "Senhor, perdoai-os porque não sabem o que fazem" e outra por aqueles que jaziam junto a mim, retorcendo-se de dor; "Senhor, concedei-lhes a fé... para que vejam; dai-lhes força para suportar a dor". Quando elevei a hóstia diante daqueles corpos feridos e destroçados, um grito saiu do meu coração: "Meu Senhor e meu Deus, tende compaixão deste rebanho que não tem pastor". ${ }^{13}$ "Para que creia em Vós. Lembrai-vos de que eles também devem chegar a conhecer-Vos."

Torrentes de graça brotariam, sem dúvida, daquela hóstia e daquele altar. Seis meses mais tarde, quando refeitos, todos tinham deixado nossa casa (somente duas pessoas lá morreram), muitos daqueles japoneses tinham sido batizados e todos tinham tido a experiência de que a caridade cristã sabe compreender, ajudar e dar um consolo que está acima de todo alento humano. Esta caridade tinha comunicado uma serenidade que nos ajudou a sorrir na dor e até mesmo a perdoar quem os fizera sofrer. ${ }^{14}$

Ao concluir a missa, Pedro e seus companheiros reuniram-se para pensar no que iriam fazer. A alimentação reforçada, para ajudar no processo autocurativo da natureza, não bastava. Outro fato providencial os esperava.

\section{Um saco de ácido bórico}

Às oito da manhã, um aldeão, que era empregado da casa, apresentou-se ao Pe. Arrupe com um saco nas mãos.

- Padre, também eu gostaria de ajudar essa pobre gente; procurando daqui e dali, dei com este saco, cheio de umas escamas brancas que parecem remédio. Veja se podem ser úteis.

O conteúdo eram quinze quilos de ácido bórico que vinha trazer a solução do problema. Utilizando-se da roupa de baixo dos lençóis que havia em casa, Arrupe preparou uma grande quantidade de faixas e iniciou um trabalho sumamente primitivo, mas que produziu ótimo resultado.

Consistia em pôr uma gaze sobre a ferida, mantendo-a úmida o dia inteiro com uma solução desinfetante de ácido bórico. Dessa forma, conseguia-se acalmar um pouco a dor e, além disso, a lesão ficava relativamente limpa e em contato com o ar. A supuração era absorvida pela gaze e, trocando-a quatro ou cinco vezes ao dia, conseguiu-se garantir a assepsia. 
Pondo em prática esse processo curativo, Arrupe notou, antes de uma semana, como se iam formando e estendendo, pouco a pouco, umas granulações de cicatrização que, devidamente cultivadas, levaram as vítimas ao restabelecimento, de modo lento, mas total. Assim eram tratados todos os casos, e Arrupe observou que não houve caso algum de contração ou queloide, que é a degeneração maligna das cicatrizes.

E o Pe. Arrupe acrescenta:

Quando, depois de certo tempo de estudo científico acerca dos efeitos da bomba atômica, um grupo de médicos da ABCC (Atomic Bomb Casuality Center) nos manifestou suspeita de que a bomba tivera influências malignas nos processos de cicatrização, pudemos mostrar-lhes que tal não sucedera, uma vez que, em centenas de vítimas que tínhamos curado, não houve um caso sequer dessas degenerações malignas. Isso nos leva a pensar que os queloides não foram causados pela bomba, e sim pelo mau tratamento das feridas.

Efetivamente, quando estávamos em Hiroshima e víamos todos aqueles processos curativos que estavam empregando, entendíamos perfeitamente porque as feridas pioravam em vez de cicatrizarem.

Em primeiro lugar, a escassez de médicos era angustiante. Dos duzentos e sessenta que havia na cidade, pereceram duzentos na explosão; dos sessenta restantes, muitíssimos ficaram feridos. Encontrei o diretor do hospital da Cruz Vermelha debaixo do telhado de sua casa, donde o tiramos com seis fraturas, impossibilitado de ajudar os demais.

Multidões de feridos caíram, pois, nas mãos de curandeiros improvisados ou de enfermeiras com curso incompleto. Muitas vezes vimos intermináveis filas de cem, cento e cinquenta feridos, esperando pacientemente na rua, ante um edifício meio destruído, para poderem passar por uma dessas enfermeiras: com um fude - pincel para escrever caracteres - iam pincelando as chagas com mercurocromo, que traziam dentro de uma lata! Como se sabe, o mercurocromo causa a destruição dos tecidos.

Estes eram os curativos "técnicos", porque os "domésticos" eram muito piores. A terapêutica caseira sempre deve ser temida, de modo especial no Japão. Neste país pensam, por exemplo, que uma polpa de nabos é muito boa para queimaduras; ora, como em Hiroshima havia nabos à vontade, aplicavam-nos nas feridas em grandes quantidades.

A princípio, o efeito era refrescante, mas ao cabo de meia hora, com o sol de agosto e o pus que saía das feridas, produzia-se uma crosta que causava dores insuportáveis. Para remediar as dores, aplicavam purê de batatas, que só fazia engrossar a crosta; esta representava uma aparência de cicatriz, mas, quando tocada, deixava perceber que havia matéria mole por baixo. Para absorver essa matéria por osmose, pulverizavam a ferida, falsamente cicatrizada, com pó ou cinza de carvão vegetal. Finalmente, com o aumento da dor, procuravam aliviá-la derramando azeite por cima. Em resumo, todo esse processo curativo caseiro produzia uma crosta duríssima, negra e luzidia como couro de sapatos recém-engraxados! 
Por isso, nosso trabalho era de ir percorrendo, uma a uma, as casas onde havia feridos, para convencê-los de que aquilo levaria à morte certa. Mas, ao mesmo tempo, lhes ensinávamos também nossos métodos e processos simples de cura. Por causa desse trabalho, naquelas primeiras semanas, podem-se contar, nos dedos das mãos, todas as horas que conseguimos dormir! Quando se sabe que uns quinze minutos de trabalho significarão, talvez, a salvação de várias vidas, não se tem tranquilidade para retirar-se a dormir. ${ }^{15}$

A esse testemunho singelo do próprio protagonista, acrescente-se o reconhecimento unânime do comportamento heroico de Pe. Arrupe, durante aquelas semanas de bomba atômica. Não parou um só instante. ${ }^{16}$

\section{Vá fundo, Padre!}

Entre os inúmeros casos individuais que atendeu, o próprio Pe. Arrufe assinala alguns de modo especial.

Eu estava em Nagatsuka, cuidando dos feridos, quando se apresentou a mim um jovem casal. Ela estava muito bem, por ter-se encontrado fora da cidade, no momento da explosão; seu marido, jovem de uns 22 anos, é que vinha numa situação lamentável, mal podendo mover-se. Ajudado pela mulher, que o conduzia, veio se arrastando em direção a nossa casa. Por onde passava ia deixando marcas de pus. A metade do seu corpo era chega viva.

Era o primeiro caso tão grave que eu via; pensei que aquele pobre homem tinha vindo ali para morrer entre nós. Mas ele, ao perceber que eu titubeava, agarrou-me uma das mãos e me disse cheio de angústia:

- Padre, ajude-me!

A mulher agarrou minha mão e explicou:

- Por favor, Padre, faz apenas um mês que nós dois nos casamos; salve meu marido!

Eu não sabia que dizer. Nessas ocasiões mil coisas nos passam pela cabeça em um segundo apenas. Afinal, quase num ato reflexo, respondi aos dois:

- Está bem, veremos o que se pode fazer, mas aviso-lhe que vai doer, e muito!

Ele me disse com olhar firme:

- Vai doer muito? Vá fundo que eu aguento!

Colocamo-lo na mesa de operação, a do meu escritório, e começamos a limpeza. Como se retorcia aquele pobre rapaz! Eu tinha de fazer o trabalho a sangue frio, porque o pus tinha se solidificado no fundo das queimaduras, e ele, no meio de suas dores, me repetia:

- Vá fundo, Padre, que eu aguento; mas salve-me!

Alguém me disse ao ouvido:

- Não há jeito de machucá-lo menos?

Era impossível; eu tinha de ser o verdugo daquele homem, se quisesse salvar sua vida, e foi o que fiz durante duas horas e meia. Ao terminar, ele estava a ponto de arrebentar-se de tanta dor e eu esgotado pela tensão que suportara, enquanto o crucificava com aquela dor. 
No Japão, como as paredes são muito finas, ouve-se todo barulho do outro lado... O rapaz esqueceu-se desse fato e, apenas saímos da sua vista, descarregou toda a dor represada sobre sua jovem esposa; toda a sua bílis, acumulada durante aquelas horas de tormento, foi despejada com os palavrões do mais baixo calão!

Ela, porém, não se alterava. Como boa japonesa, escutava-o sorrindo e, por vingança, ascendia-lhe um cigarro e the enxugava o suor ou the dava alguma coisa para beber. E assim foi nos dias seguintes em que sempre a encontrávamos sorrindo, sentada ou ajoelhada à cabeceira do esposo. Nunca chegamos a descobrir quando dormia.

Depois de oito meses, essa casal saiu da nossa casa. Numa manhã de abril, eu os vi descer a encosta do jardim, sorridentes, felizes e, sobretudo... batizados! Naquele momento, senti também eu uma alegria intensa que compensava todos os sofrimentos daqueles oito meses passados. Porque se tivéssemos deixado aquele rapaz sem atendimento, teria morrido, sem dúvida alguma, uma vez que já apresentava os primeiros sinais de infecção. ${ }^{17}$

Outro caso que produziu vivo impacto na alma do Pe. Arrupe foi o de Nakamura-san, aquela universitária que conhecera em Yamaguchi e que agiu tão heroicamente ao ser caluniada. Essa moça tinha ido viver em Hiroshima, e o Padre não conseguia notícias dela desde que a bomba explodira. Duas semanas mais tarde, ficou sabendo que estava ferida e ele, minutos depois, já estava nas ruas da cidade procurando-a, quase às cegas, entre os escombros de casas semidestruídas. Era difícil orientar-se sem ponto de referência, mas, após quatro horas de busca, algumas moças lhe disseram:

- Por ali, senhor, virando aquela esquina.

Arrupe seguiu a direção indicada e encontrou alguns paus sustentando um teto de latas chamuscadas e uma parede de meio metro de altura, fechando um pequeno cômodo. Quis entrar, mas o insuportável mau cheiro o fez recuar. Nakamura-san estava estendida no chão com os braços e as pernas estendidas. Trazia os membros todos inchados e convertera-se numa só queimadura, da qual brotava pus em fiozinhos turvos que caíam empapando o chão. A carne fora tão destruída que só se viam pele e osso.

Assim permanecera quinze dias sobre aquela tábua rude, sem que ninguém a pudesse nem mesmo limpar, comendo apenas um pouco de arroz trazido por seu pai, também ferido. Suas costas eram uma chaga enorme, meio gangrenada, por não ter podido mudar de posição todo aquele tempo. Ao limpar a queimadura numa das coxas, Arrupe viu a massa muscular corrompida e tornada pus, uma ferida muito profunda em que cabia um punho fechado e se viam até vermes.

Arrupe estava aniquilado, sem poder dizer palavra. Nakamura-san abriu os olhos e, ao reconhecer o Padre, pronunciou esta frase, da qual ele jamais se esqueceria:

- Arrupe shimpu-sama, Goseitai, o motie irasshaimashita ka? (Pe. Arrupe, o senhor está me trazendo a comunhão?) 

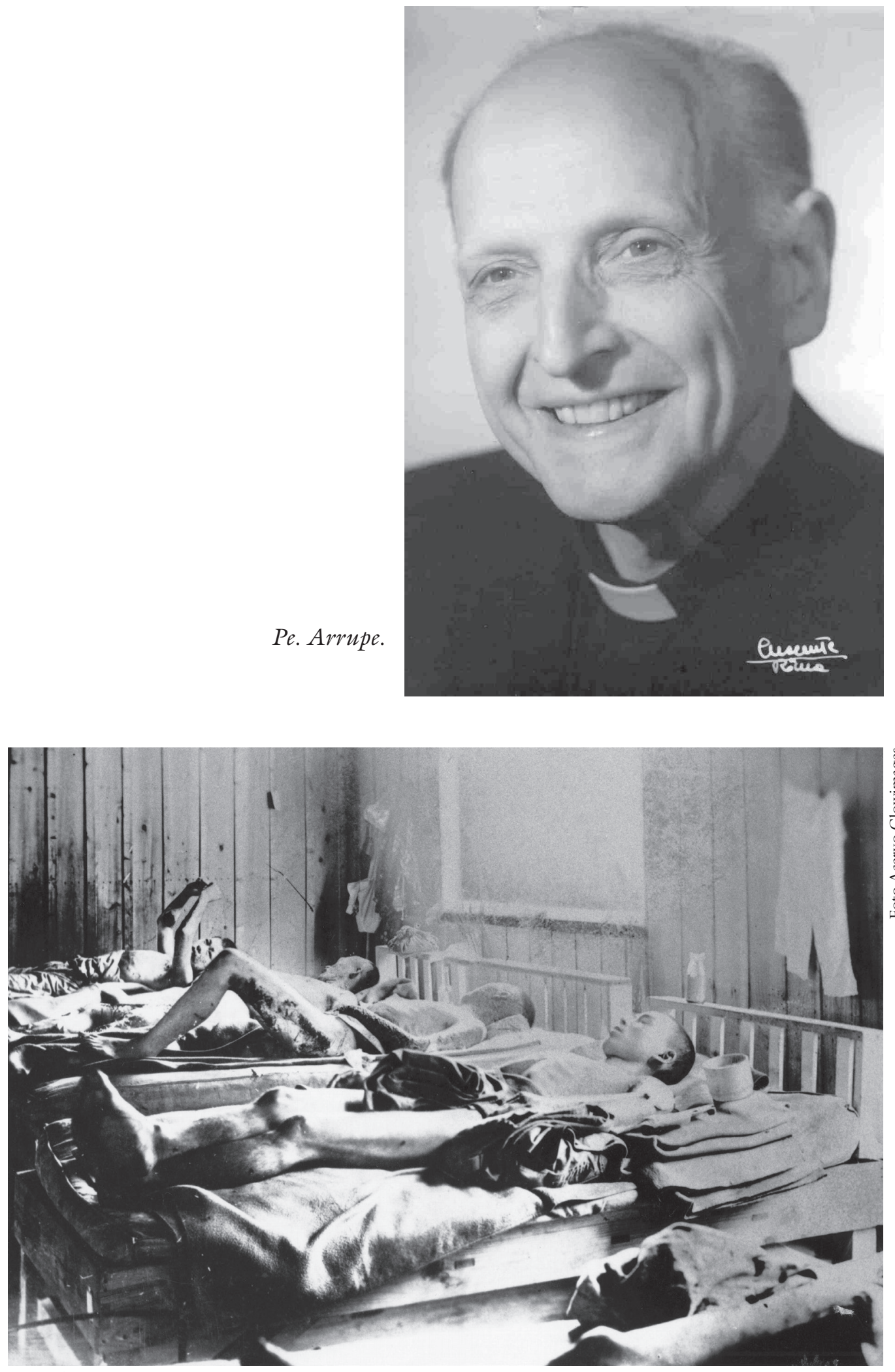

Vitimas da bomba de Hiroshima. 
O Padre agiu com rapidez e a fez transportar como pôde para Nagatsuka. Os curativos eram terríveis; a febre fazia a pobre moça delirar, imaginando um fantasma que tentava sufocá-la, apertando-lhe o pescoço. Quando o Padre se aproximava, ela se tranquilizava pouco a pouco. Pensando que ela já dormia, ele procurava afastar-se; ela, porém, ao ver que se retirava, inquietava-se de novo. Não houve outro jeito senão velar, ao lado dela, noites seguidas.

Depois de dois meses, quando parecia que se estava recuperando lentamente, um ataque cardíaco a levou. Seu pai encarregou-se de cremar-lhe o corpo perto da casa. Na metade da cremação, porém acabou-se a lenha e o homem foi chamar Arrupe, ao qual tocou ainda o último ato dessa dolorosa tragédia: contemplar, à noite, o cadáver de Nakamura-san, com um rictus de dor no rosto e na carne meio calcinada pelo fogo. ${ }^{18}$

Os casos atendidos por Arrupe são inumeráveis. Entre eles, suas memórias nos falam de muitas crianças. Quando a bomba explodiu, a imensa maioria delas, devido ao alto nível de escolarização do Japão, estava nas escolas e colégios. Por isso, ao cair a bomba, milhares de meninos e meninas ficaram separados de seus pais, feridos, atirados para longe ou à deriva, pelas ruas da cidade, sem poderem fazer coisa alguma por si mesmos.

Pe. Arrupe recolheu todos os que pôde, dedicando-se a fazer neles os devidos curativos para prevenir infecções e febres. Destaquemos um desses casos tirados das notas do próprio Padre:

Carecíamos de anestésicos, e muitos estavam horrivelmente feridos; um desses meninos, por causa de uma telha que lhe caíra em cima, tinha corte que ia de orelha a orelha. Era um ferimento de um centímetro e meio de largura, separando o couro cabeludo e deixando o crânio à vista, tudo isso cheio de barro e cacos de vidro.

Durante os curativos, os gritos dessa pobre criatura deixavam toda a casa suspensa. Vimo-nos forçados a amarrá-lo num carrinho com um lençol, levando-o para o alto de uma colina, junto da casa. Aquele lugar virou, então, sala cirúrgica, onde podíamos trabalhar e o menino gritar sem deixar nervosos os demais.

O coração doía ao termos de fazer essas coisas; mas muito maior era o consolo de poder devolver essas crianças a seus pais. Através da polícia japonesa, muito bem organizada, pudemos entrar em contato com as famílias de todos os meninos e meninas que tínhamos em casa.

Pouco a pouco, esses pais começaram a chegar a Nagatsuka, vindos de Osaka, Tóquio e muitas outras cidades. Impossível descrever a cena dos encontros com filhos que julgavam mortos na explosão e que agora recebiam nos braços, são e salvos ou, pelo menos, em processo de cura. Aqueles pais e mães, cheios de emocionada alegria, não sabiam como expressar seu agradecimento; atiravam-se aos nossos pés e, nessa atitude, traziam-nos à mente as cenas descritas nos Atos dos Apóstolos, quando os judeus caíam de joelhos diante dos apóstolos, adorando-os como deuses. ${ }^{19}$ 


\section{Patologia radiativa}

Mas, em meio àquelas impressões, havia algo que desconcertava o ex-aluno da Faculdade de Medicina de San Carlos, de Madrid. Muitas pessoas que estavam na cidade no momento da explosão não tinham sofrido ferimento algum; entretanto, depois de alguns dias, sentiam-se fracas e acorriam ao Pe. Arrupe, dizendo que estavam se abrasando em calores internos e temiam ser o efeito de gases venenosos que teriam respirado... E logo morriam.

O primeiro caso ocorreu quando Arrupe estava fazendo curativos num ancião que tinha duas feridas muito profundas nas costas. Apresentou-se-lhe, na ocasião, um senhor que lhe disse:

- Por favor, venha a minha casa, porque meu filho está com muita dor de garganta.

Com o caso do ancião era muito grave, Arrupe disse ao homem:

- Provavelmente é um resfriado. Dê-lhe aspirina e um suadouro. Verá como fica bom.

Duas horas depois, o menino morria. Que teria acontecido?

Pouco depois foi ter com Arrupe, chorando, uma menina de 13 anos que lhe disse:

- Olhe o que me está acontecendo!

E abrindo a boca mostrou-lhe as gengivas sangrando. Tinha toda a cavidade bucal cheia de feridas pequenas e uma faringite aguda. Além disso, bastava puxar um pouco os cabelos que estes lhe ficavam na mão aos punhados. Morreu dois dias depois.

Arrupe compilou todos esses dados. Os sintomas eram os seguintes: destruição dos órgãos hematopoéticos, medula, baço, gânglios linfáticos e bulbos capilares. Em uma palavra, eram os sintomas de uma nova enfermidade, a patologia radiativa. Ao conhecer essas causas, o Padre pôde salvar algumas vidas, por meio de transfusões de sangue e outras medidas adequadas.

Mais tarde, tipificaria os efeitos da bomba, reconhecendo três tipos de onda: a onda explosiva, cujos efeitos são como os de qualquer bomba e que atuou num raio de ação de seis quilômetros; a onda térmica, que atingiu uma temperatura de dez milhões de graus e que produziu radiações infravermelhas capazes de destruir os tecidos; e, finalmente, a onda radiativa que se estendeu a um raio de ação de um quilômetro e meio. Esta causava diminuição dos glóbulos vermelhos e brancos, hemorragia nas gengivas, boca e garganta, manchas na pele, queda dos cabelos, vômitos, febre alta etc.

\section{Sombras de Hiroshima}

As famosas sombras de Hiroshima, que deixaram silhuetas humanas sobre algumas paredes, não foram causadas, segundo Arrupe, pela desintegração dos corpos, mas pela sua calcinação. A elevação da temperatura na onde térmica foi instantânea; se, naquele momento, dentro dessa onda, houvesse uma pessoa 
encostada contra uma parede, ela era calcinada em um segundo, funcionando como um escudo para a parede e deixando nela marcada a sua sombra ou silhueta.

É importante levar em conta que Arrupe viveu toda essa incrível peripécia, única na história, dentro de um isolamento total: sem telefone, telégrafo, rádio, eletricidade nem qualquer tipo de transporte. A cidade de Hiroshima só recebeu auxílios externos, provenientes de Tóquio e Osaka, a partir do dia seguinte à explosão da bomba. Muitas das pessoas que vinham trazendo auxílios paravam aterrorizadas às portas da cidade, com medo de entrar e de serem afetadas pela radiação.

O próprio Pe. Arrupe, que já entrara várias vezes na cidade sinistrada para socorrer os feridos, ouvia dizer:

- Não entrem! Há lá um gás que mata e levará sessenta anos para desaparecer.

Mas era exatamente aí que ele se sentia mais estimulado a gastar-se no serviço aos enfermos e agonizantes. Ali dentro havia cinquenta mil cadáveres que, se não fossem queimados, dariam origem a uma terrível peste e, sobretudo, cento e vinte mil feridos lá estavam à espera de cuidados e curativos. "Diante de tal situação - escreve Arrupe -, um sacerdote não pode ficar de fora para salvar a própria vida."

E acrescenta:

Naturalmente, quando alguém nos diz que dentro da cidade há um gás mortífero, a gente só decide entrar depois de um propósito muito firme. Nós o fizemos e começamos a amontoar enormes pirâmides de cadáveres, para empapá-los de petróleo e atear-lhes fogo. Assim desapareceram os cadáveres que estavam nas ruas.

Mas havia muitos outros escondidos. Com o sol de agosto e o calor úmido, o mau cheiro nos ia dizendo onde havia mais corpos em putrefação. Levantávamos, então, os escombros e encontrávamos famílias inteiras de cinco, seis ou mais pessoas, esmagadas sob suas casas. Ajudados pelos transeuntes que porventura passavam, amontoávamos até cinquenta ou sessenta cadáveres para incinerá-los.

Ao terminar, num último esforço, aquela penosa tarefa dos primeiros dias, estávamos esgotados; mas o cansaço nos fazia esquecer o gás que matava; por isso perguntávamos uns aos outros:

- Você está sentindo algo?

E todos sentiam o mesmo: estávamos cansados sim, mas sem sintomas especiais que nos pudessem alarmar. Era natural que assim fosse, uma vez que o falso rumor do gás mortífero só tinha fundamento na imaginação superexcitada das pessoas, diante do espetáculo tão horrendo daquele calvário. ${ }^{20}$

Mas, acreditem ou não, o pior veio no fim. Terminada a guerra, Arrupe e seus noviços foram obrigados a deixar a casa e a cidade. Desta vez não foi por acusação de espionagem, porque as hostilidades já tinham cessado; foi por 
um certo revanchismo contra estrangeiros, depois da suprema humilhação de derrota japonesa. Nem levaram em conta o comportamento heroico daquela comunidade e daquela casa convertida em hospital para as vítimas da bomba!

Ante a ordem de despejo, Arrupe respondeu inteligentemente:

- Está bem; somos quarenta e cinco; digam-nos, pois, para onde ir.

A ordem foi repetida quatro vezes, e o Padre lhes repetia sempre que não tinham onde morar. Até que, afinal, apareceram quatro agentes oferecendo-lhes um hotel junto a um lago em Taisaku, um belo local, rodeado de montanhas, numa situação muito saudável.

Os jovens jesuítas partiram para a região montanhosa; ninguém, entretanto, conseguiu fazer Arrupe abandonar os cento e cinquenta enfermos que ainda tinha em casa. Ele era o único médico ali e não confiava nas mezinhas dos japoneses. Ficou, pois, em Nagatsuka, acompanhado de outros cinco padres.

Quinze dias mais tarde, os noviços receberam ordem de voltar das montanhas, uma vez que já não havia perigo em Hiroshima. Arrupe ficou muito satisfeito com isso porque, afinal, sem tê-lo planejado nem pretendido, conseguira férias gratuitas para os estudantes. E bem que o mereciam, pelo heroico trabalho de atender os destroçados pela bomba.

\section{Notas}

1 Cf. Raymond Carter, La Seconde Guerre Mondiale (2v.) Paris, 1966, p.353ss. Sobre a bomba atômica, cf. também G. Alperovitz, Atomic diploma: Hiroshima and Potsdam, New York, 1965; S. Arrisue, Memoirs, Tóquio, 1974; S. Ashi, A Bomb, Hiroshima, 1972; I. W. Campbell, The atomic story, New York, 1947; Herbert Feis, The atomic bomb and the End of World War Two, Princeton, 1966; Michihiko Hachlya, Hiroshima diary, North Carolina, 1955, 10.ed. 1985; G. Thomas, M. L., Morgan Witts, Enola Gay, New York, 1977 [última edição, 1985]; e a documentação de Masuji Ibuse, Black rain, San Francisco, 1969.

2 Para a narração da peripécia do comandante Tibbets, cf. Enola Gay, best-seller mundial e documentação sobre o lançamento.

3 R. Cartier, op. cit., p.353ss.

4 Da narração do Pe. Arrupe existem diversas versões. Além das suas memórias, Este Japon increible, nas quais narra mais amplamente sua experiência em Hiroshima, ele completou suas vivências numa obra ulterior, Yo viví la bomba atomica, México, 1965. Mas existem centenas de outras versões em jornais e revistas ou em forma de entrevistas, nas quais ele sintetiza ou acrescenta alguma coisa. Entretanto, para maior clareza continuaremos citando basicamente o primeiro livro, com o título de Memórias, como temos feito, completando às vezes com outras fontes.

5 Memórias, p.171ss.

6 Ibidem, p.211.

7 Ibidem, p.213. 
8 É muito interessante comparar os diagnósticos do Pe. Arrupe com os de outro médico, um japonês que sobreviveu também à bomba atômica, o Dr. Michihiko Hachiya, autor do impressionante livro Hiroshima diary, na tradução inglesa do também médico Warner Wells que, dia a dia, se defrontava com a nova e estranha doença provocada pela radiação atômica. Um relato escrito naqueles dias trágicos, cheio de compaixão de ternura (há versão castelhana; Diário de Hiroshima, Buenos Aires: Emecé, s. d.).

9 Memorias, p.215; Yo viví la bomba atômica, p.209.

10 Yo vivi la bomba atômica, p.209.

11 Jo $1,26$.

12 Jo $1,26$.

13 Mt. 9,39; Mt 6,34; 1Tm 2,4.

14 Itinéraire, p.44.

15 Memorias, p.22; Yo vivi la bomba atômica, p.211.

$16 \mathrm{O}$ Autor deste livro entrevistou mais de trinta pessoas em Hiroshima, que tinha conhecido e tratado com o Pe. Arrupe durante o período da bomba. Todos, unanimemente, declararam que seu comportamento naqueles dias foi algo mais que heroico: sua resistência e capacidade de trabalho, quase sem dormir; sua intuição, eficácia e rapidez mental para resolver os problemas e, sobretudo, sua imensa fé os deixava a todos estupefatos. Muitas das pessoas que foram atendidas por ele como médico acabaram pedindo o batismo mais tarde, cativadas pelo exemplo cristão deste homem singular. Entretanto, conforme ele mesmo declarou anos mais tarde a sua sobrinha Mariví Gondra, Arrupe não quis explorar os seus dotes de "taumaturgo", diante do povo. "Não teriam sido conversões verdadeiras; mesmo que se tivessem batizado centenas de pessoas."

Procuremos atualizar alguns dados sobre os efeitos da bomba atômica: a primeira bomba atômica explodiu praticamente no centro de Hiroshima, a uma altura de quinhentos e oitenta metros, sobre o hospital Shima, localizado no coração da cidade. A bomba soltou uma energia equivalente a 12,5 quilotões de TNT. O enorme globo de fogo, semelhante a um pequeno sol, provocou, pela intensidade do calor no seu contato com o ar, uma espécie de tufăo. Comprovou-se que $15 \%$ da sua energia traduziu-se em energia radiativa; $35 \%$ em calor e $50 \%$ em força explosiva.

O balanço total foi que, entre trezentos e dez mil e trezentos cidadãos e mais de quarenta mil soldados foram diretamente afetados pela bomba. Destes, uns cento e cinquenta mil, incluindo vinte mil soldados, morreram até o final de dezembro de 1945; 90\% destes já tinham falecido nas primeiras semanas depois da explosão.

Naquela época, havia em Hiroshima uns setenta e seis mil edifícios, dos quais 92\% foram destruídos pela explosão e pelos incêndios subsequentes. A onda explosiva cobriu todo o delta sobre o qual está a cidade, chegando a destruir também $60 \%$ das casas construídas em bairros situados a cinco quilômetros do epicentro. Ao que parece, apenas $8 \%$ das casas nos arredores mais afastados puderam ser recuperadas. A área afetada pela bomba atingiu treze quilômetros quadrados em torno do epicentro.

Tanto se falou de Hiroshima que se costuma esquecer de que, três dias depois da tragédia, 9 de agosto de 1945, os americanos fizeram explodir outra bomba atômica sobre Nagasaki. Esta bomba tinha quase o dobro de poder destrutivo, quase 22 quilotões de TNT. Calcula-se em trezentos mil graus a temperatura desenvolvida um décimo de 
milésimo de segundo depois da explosão. Como em Hiroshima, a energia calorífica causou a maior parte dos danos que afetaram entre duzentas e setenta e duzentas e oitenta mil pessoas. Apesar da maior capacidade destrutiva da bomba de Nagasaki, o fato de seu epicentro se encontrar perto das colinas da parte norte desta cidade marítima, afastadas das ruas mais transitadas, reduziu em parte os efeitos destrutivos desta segunda bomba (cf. Days to remember, preparado pelo comitê de cidadãos japoneses em Hiroshima e Nagasaki, de agosto de 1981).

Causa calafrios a visita feita aos museus de paz que existem tanto em Hiroshima como em Nagasaki, assim como os parques da paz, criados como memoriais de ambas as catástrofes. Em Hiroshima, o museu e o parque estão situados no epicentro da bomba onde se conserva também o edifício da Prefeitura para a Promoção da Indústria, hoje conhecido como "Atomic Dome", cujo esqueleto, por ser muito resistente, aguentou o choque e permanece de pé, do jeito que ficou depois da explosão.

17 Yo viví la bomba atômica, p.212.

18 Memorias, p.222.

19 Yo vivi la bomba atômica, p.213.

20 Ibidem, p.215.

Referência do texto:

Capítulo 11. "A Bomba”, extraído do livro:

LAMET, P. M. Arrupe. Da bomba de Hiroshima à crise pós-conciliar. São Paulo: Edições Loyola, 1992.

Pedro Miguel Lamet é religioso jesuíta, jornalista e escritor espanhol. http://www.pedrolamet.com 
